As reported by Olivieri et $a l^{5}$ in other rheumatic conditions associated with distal extremity swelling with pitting oedema, magnetic resonance imaging confirmed in three patients the clinical impression that a severe tenosynovitis of peroneal, tibialis, and extensor tendons was the main lesion responsible for the oedema in the subcutaneous and peritendineous ankle and foot soft tissues. A slight joint synovitis with scanty intrarticular fluid was present (fig 2).

Similar findings were reported by Kellner et $a l^{P}$ by using ultrasound to study ankle swelling in acute sarcoidosis. Sonographic features of tenosynovitis were detected in eight of 24 patients, only in two cases a concomitant arthritis was found.

In conclusion our cases confirm that a tenosynovitis is part of the spectrum of articular manifestations of sarcoidosis. Moreover, our clinical series suggest that distal extremity swelling with pitting oedema over the dorsum of feet may be the presenting feature of acute sarcoidosis. Consequently the disease may be included among the rheumatic disorders associated with remitting distal extremity swelling and pitting oedema.

FABRIZIO CANTINI

$2 \wedge$ Divisione di Medicina, Ospedale di Prato IGNAZIO OLIVIERI Servizio di Reumatologia, Policlinico Orsola-Malpighi, Bologna

LIBERO BAROZZI Servizio di Radiodiagnostica, Policlinico S Orsola-Malpighi, Bologna

ALESSANDRO BOZZA Istituto Pratese di Radiodiagnostica, Prato PIER LUIGI MACCHION ANGELA PADULA

2^Divisione di Medicina, Arcispedale S Maria Nuova, Reggio Emilia, Italy

Correspondence to: Dr F Cantini, 2^ Divisione di Medicina, Ospedale di Prato, Piazza Ospedale, 1-50047, Prato, Italy.

1 McCarty DJ, O'Duffy JD, Pearson L, Hunter JB. Remitting seronegative symmetrical synovitis with pitting edema. $\mathrm{RS}_{3} \mathrm{PE}$ syndrome. JAMA 1985;254:2763-7.

2 Salvarani C, Gabriel S, Hunder GG. Distal extremity swelling with pitting edema in polymyalgia rheumatica. Report of nineteen cases. Arthritis Rheum 1996;39:73-80.

3 Olivieri I, Padula A, Pierro A, Favaro L, Oranges GS, Ferri S. Late onset undifferentiated seronegative spondyloarthropathy. J Rheumatol 1995;22:899-903.

4 Olivieri I, Padula A, Favaro L, Pierro A, Oranges GS, Ferri S. Dactylitis with pitting oedema of the hand in longstanding ankylosing spondylitis. Clin Rheumatol 1995; ing spondyl

5 Olivieri I, Salvarani C, Cantini F. Remitting distal extremity swelling with pitting edema: a distinct syndrome or a clinical feature of distinct syndrome or a clinical feature of Rheumatol 1997;24:249-52.

6 Spilberg I, Siltzbach LE, McEwen C. The arthritis of sarcoidosis. Arthritis Rheum 1969; 12:126-37.

7 Perruquet JL, Harrington TM, Davis DE, Viozzi FJ. Sarcoid arthritis in a North American Caucasian population. J Rheumatol 1984 11:521-5

8 Caplan HI, Katz WA, Rubenstein M. Periarticular inflammation, bilateral hilar adenopathy, and sarcoid reaction. Arthritis Rheum 1970; 13:101-10

9 Kellner H, Spathling S, Herzer P. Ultrasound findings in Lofgren's syndrome: is ankle swelling caused by arthritis, tenosynovitis or periaring caused by arthritis, tenosynovitis
thritis. J Rheumatol 1992;19:38-41.

10 Mana J, Gomez-Vaquero C, Salazar A, Valverde J, Juanola X, Pujol R. Periarticular ankle J, Juanola X, Pujol R. Periarticular ankle Rheumatol 1996;23:874-7.

\section{Further evidence that low androgen values are $a$ cause of rheumatoid arthritis: the response of rheumatoid arthritis to seriously stressful life events}

It is well established that androgen concentrations are low in patients with rheumatoid arthritis (RA). ${ }^{1}$ There are three possibilities: (1) Low androgen values are a consequence of RA. (2) Low androgen values are a consequence of its treatment. (3) Low androgen values are a partial cause of RA.

Undoubtedly the facts are complex, but in what I take to be an excess of methodological correctness, Masi et al ${ }^{1}$ write: 'The available evidence reviewed does not allow definitive response to the question of a primary versus secondary role of sex hormone perturbations in RA'. I shall treat the three above possibilities in turn to suggest that (in contrast with Masi et $a l^{1}$ ) a definitive response is possible.

(1) Low androgen concentrations in men are a consequence of many forms of illness ${ }^{2}$ including severe inflammatory disease, ${ }^{3}$ so it may be accepted that this is one cause of the low androgen values.

(2) Acute and chronic administration of exogenous glucocorticosteroids can lower testosterone and DHAS. (See Masi et al for reference). So this may be another cause of low androgens in patients so treated.

(3) However there are very substantial grounds for suspecting that low androgens are a partial cause of RA too: (a) RA is more common in women than in men. (b) RA is associated with HLA B $15,{ }^{4-5}$ which in turn is associated with low androgen values in men. ${ }^{6}$ Hence the suggestion that low testosterone is a genetically determined precursor, rather than a consequence of RA or its treatment. A similar argument may be deployed in regard to HLA DR 4 in women. ${ }^{7}$ (c) RA abates in about $75 \%$ of cases during pregnancy. (See Masi et $a l^{1}$ for references). Some weeks to months after delivery, the disease flares in more than $90 \%$ of these patients. During pregnancy, increasing quantities of androgens are produced by the corpus luteum, placenta, and fetal testes and adrenal glands. According to this hypothesis, amelioration during pregnancy is caused by these hormones, and the subsequent relapse is caused by their withdrawal. (d) Controls have been shown to have higher testosterone concentrations than patients in case-control studies: these data are consistent with any of the three propositions above. But the point has been established in a longitudinal study too: women who later developed RA had significantly lower DHAS values than controls who did not later develop the disease. ${ }^{9}$ Such a finding, if it were confirmed would not be adequately explained by propositions 1 or 2 . (e) Direct administration of testosterone to male $^{10}$ and postmenopausal female patients ${ }^{11}$ has resulted in improvement. It would be interesting to see the effect of such treatment for premenopausal patients.

In the attempt to further inculpate low testosterone values in the aetiology of RA, I wish to draw attention to further confirmatory evidence in the shape of two dramatic cases reported in the behavioural literature.

The first is that of an elderly female RA patient who survived a lightning strike during a thunderstorm. Her walking stick was allegedly charred and her symptoms almost totally abated, ${ }^{12}$ though they subsequently returned before her death. I can vouch for the authenticity of the substance of this story: the lady was my aunt and she certainly suffered a shock (though not necessarily an electrical one). She regarded her experience as the occasion of a miracle.

The second case was that of a 53 year old female RA patient who suffered the unexpected deaths of her son and husband. ${ }^{13}$ Her disease went into temporary remission within a week of the deaths.

Stress in both sexes leads to increased pituitary secretion of adrenocorticotropic hormone. In men this causes reduced gonadal steroid production. ${ }^{3}$ In women, adrenocorticotropic hormone activation of the adrenal cortex is suspected of leading to increased overall androgens. ${ }^{14}$ (In women, the main source of androgens is the adrenal gland whereas in men it is the gonads). So I suggest that these two cases illustrate the beneficial effects of androgens on RA.

There are two ways in which this could be tested: (1) If I am right, such seriously stressful life events would have an exacerbating effect on male patients. (2) If I am right, the beneficial effects of pregnancy should be more evident in women carrying male fetuses (because male fetuses secrete more androgens than female fetuses).

WILLIAM H JAMES

The Galton Laboratory, University College London, Wolfson House, 4 Stephenson Way London NW1 $2 H E$

1 Masi AT, Da Silva JA, Cutolo M. Perturbations of hypothalamic-pituitary-gonadal (HPG) axis and adrenal androgen (AA) functions in rheumatoid arthritis. Baillière's Clin Rheumatol 1996;10:295-332.

2 Semple CG. Hormonal changes in nonendocrine disease. BMJ 1986;293:1049-52.

3 Semple CG, Gray CE, Beastall GH. Adrenal androgens and illness. Acta Endocrinol 1987:16:155-60.

4 Ollier W, Venables PJW, Mumford PA, Maini R, Awad J, Jaraquemada D, et al. HLA antigen association with extra articular rheumatoid arthritis. Tissue Antigens 1984:24:279-91.

5 Jaraquemada D, Ollier W, Awad J, Young A, Silman A, Roitt IM, et al. HLA and rheumatoid arthritis: a combined analysis of 440 patients. Ann Rheum Dis 1986;45:627-36.

6 James WH. Rheumatoid arthritis, the contraceptive pill, and androgens. Ann Rheum Dis 1993:52:470-4.

7 Deighton CM, Watson M, Walker DJ. Rheumatoid arthritis, sex ratios, HLA-DR and testosterone. Ann Rheum Dis 1993;52:244.

8 Buster JE, Simon JA. Placental hormones, hormonal preparation for and control of parturition and hormonal diagnostic of pregnancy. In: De Groot LJ, Besser GM, Cahill GF, et al, eds. Endocrinology. Philadelphia: Saunders, 1989:2043-73.

9 Masi AT, Feigenbaum SL, Chatterton RT. Hormonal and pregnancy relationships to rheumatoid arthritis: convergent effects with immunotoid arthritis: convergent effects with immuno-
logic and microvascular systems. Semin Arthritis Rheum 1995;25:1-27.

10 Cutolo $M$, Balleari E, Giusti M, Intra E, Accardo S. Androgen replacement therapy in male patients with rheumatoid arthritis. Arthritis Rheum 1991;34:1-5.

11 Booij A, Biewenza-Booij CM, Cornelis C, Jacobs JWG, Bijlsma JWJ. Androgen as adjuvant treatment in postmenopausal female adjuvant treatment in postmenopausal female patients with rheumatoid

12 James WH. (Letter). J Psychosom Res 1995; 39:507.

13 Potter PT, Zautra AJ. Stressful life events' effects on rheumatoid arthritis disease activity. J Consult Clin Psychol 1997;65:319-23.

14 Kemper TD. Social structure and testosterone. London: Rutgers University Press, 1990: 161. 